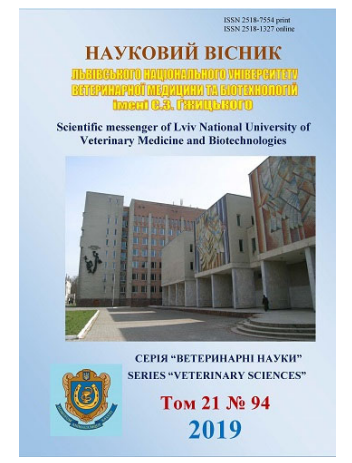

\author{
Науковий вісник Дьвівського національного університету \\ ветеринарної медицини та біотехнологій імені С.З. Гжицького. \\ Серія: Ветеринарні науки \\ Scientific Messenger of Lviv National University \\ of Veterinary Medicine and Biotechnologies. \\ Series: Veterinary sciences
}

\title{
Influence of some etiological factors on development of gynecological pathology and infertility of cats
}

\author{
O.L. Dmytryshyn, V.Yu. Stefanyk \\ Stepan Gzhytskyi National University of Veterinary Medicine and Biotechnologies Lviv, Ukraine
}

Article info

Received 05.04.2019

Received in revised form 06.05 .2019

Accepted 07.05.2019

Stepan Gzhytskyi National University of Veterinary Medicine and Biotechnologies Lviv, Pekarska Str., 50, Lviv, 79010, Ukraine. Tel.: +38-095-105-95-08 E-mail: orysya.dmytryshyn@gmail.com

Dmytryshyn, O.L., \& Stefanyk, V.Yu. (2019). Influence of some etiological factors on development of gynecological pathology and infertility of cats. Scientific Messenger of Lviv National University of Veterinary Medicine and Biotechnologies. Series: Veterinary sciences, 21(94), 66-73. doi: $10.32718 /$ nvlvet 9412

The article provides an overview of professional literature on reproductive studies of cats, the definition of the main factors influencing the development of infertility in cats: hormonal changes, lack of sufficient stimulus during pairing, leading to ovulation, inability to fuse, ovarian cyst, chronic inflammatory processes in reproductive organs systems, infections, some parasites or the simplest, hereditary problems, including chromosomal abnormalities (genetic or congenital defects such as pseudoharmophioditis, true hermaphroditism, mosaicism, infantilism, freemantry) described congenital aplasia of the ovaries, trauma affecting the reproductive organs. The conditions of detention that considerably affect the reproductive system are considered. It has been established that insufficient stimulation is one of the most common causes of infertility, which is relevant for cats because they are characterized by induced ovulation. Most animals with an abnormal set of sex chromosomes are infertile, treatment methods have not been developed. Inadequate feeding is perhaps the most important cause of infertility in cats. The connection between lack and (or) excess in the diet of Calcium, Phosphorus, Iodine, Cobalt, Cuprum, Manganese, other macro-and micro elements, and inability to reproduce is established. The role of microorganisms in the emergence of infertility of cats of infectious diseases (leukemia, infectious peritonitis, panleukopenia, chlamydia, toxoplasmosis) is considered. Extension of the intraperitoneal period arises from the stage of the anestrus. Such clinical picture is observed in cats older than 8 years with hypothyroidism and hyperadrenocorticism, obesity and cachexia, the appointment of drugs with antinuclear activity. Among gynecological diseases in cats, the most common diseases are pyometra, endometritis and vaginitis. It has been established that the most frequently diagnosed diseases of the uterus of female dogs and cats are cystular hyperplasia of the endometrium in combination with the pythometer, data on the etiopathogenesis of these diseases is given. The scientific data on the application of ultrasound diagnostics, hormonal level studies, vaginal cytology, the use of hysterosalpingography, x-ray for more accurate diagnostics of causes of infertility of cats are given.

Key words: infertility, cats, sexual cycle, fertility, chromosomal aberration, cystular hyperplasia of the endometrium, pythometer, hysterosalpingogram, ultrasonography.

\section{Вплив окремих етіологічних факторів на розвиток гінекологічної патології та неплідності кішок}

\author{
О.Л. Дмитришин, В.Ю. Стефаник
}

Львівський національний університет ветеринарної медицини та біотехнологій імені С.3. Гжиџького, м. Львів, Украӥна

У статті наведено огляд фахової літератури з репродуктології котів, визначення основних факторів, щцо впливають на розвиток неплідності у кішок: гормональні зміни, відсутність достатнього стимулу під час парування, щцо призводить до овуляції, 
нездатність до парування, кісти яєчників, хронічні запальні процеси в органах репродуктивної системи, інфекиї, деякі паразити або найпростіші, спадкові проблеми, у тому числі хромосомні аномалії (генетичні або вроджені дефекти, такі як псевдогермафродитизм, істинний гермафродитизм, мозайиззм, інфантилізм, фримартинізм), описано вроджену гіпоплазію, або аплазію яєчників, травми, щуо впливають на репродуктивні органи. Розглядаються умови утримання, що істотно впливають на репродуктивну систему. Встановлено, шчо недостатня стимуляція є однією з найпоширеніших причин неплідності, шьо є актуально саме для кішок, тому щуо для них характерна індукована овуляція. Більшість тварин з анормальним набором статевих хромосом є неплідними, методи лікування не розроблені. Неповноцінна годівля є чи не найголовнішою причиною неплідності у кішок. Встановлено зв'язок між нестачею і (або) надлишком у рачіоні Кальичію, Фосфору, Йоду, Кобальту, Купруму, Мангану, інших макро- і мікроелементів та нездатністю до відтворення. Розглянуто роль мікроорганізмів у виникненні неплідності кішок інфекційних захворювань (лейкемія, інфекиійний перитоніт, панлейкопенія, хламідіоз, поксоплазмоз). Подовження міжестрального періоду виникає за рахунок стадї анеструсу. Таку клінічну картину спостерігають у кішок, віком понад 8 років при гіпотиріоїозі і гіперадренокортицизмі, ожирінні $і$ кахексї, призначенні препаратів з антигонадною активністю. Серед гінекологічних захворювань у кішок найпоширенішими є піометра, ендометрит та вагініт. Встановлено, щзо найчастіше діагностованим захворюванням матки сук та кішок є кістозна гіперплазія ендометрію в комплексі з піометрою, подано дані про етіо-патогенез циих захворювань. Наведено наукові дані щзодо застосування ультразвукової діагностики, дослідження рівня гормонів, вагінальної ичитологї, застосування гістеросальпінгографії, рентгену для точнішої діагностики причин неплідності кішок.

Ключові слова: неплідність, кішки, статевий цикл, фертильність, хромосомні абераціі, кістозна гіперплазія ендометрію, піометра, гістеросальпінгограма, ультрасонографія.

Однією з актуальних проблем ветеринарного акушерства та фелінології $є$ вивчення проблем неплідності кішок. Етіологія захворювань репродуктивних органів дрібних домашніх тварин, що призводять до неплідності, недостатньо з'ясовані, а досконалі методи діагностики не розроблені.

На думку Е. Axner (Axner, 2010), правильний підхід щодо постановки діагнозу при неплідності кішок має грунтуватися на знанні фізіології розмноження цього виду тварин. Відсоток запліднення у кішок становить в середньому 70-80\%. Дані анамнезу про попередній перебіг вагітностей у кішок чи парувань, які відбулися із самцями, можуть допомогти зрозуміти, яка $з$ пари тварин може бути джерелом проблеми. Якщо кішка не завагітніє після трьох парувань 3 самцем із підтвердженою фертильністю, це може свідчити про іiі неплідність. Проблеми з відтворенням можуть стосуватися відсутності чи неправильного перебігу еструсу, осіменіння, овуляції, запліднення, ранньої резорбції зародків чи абортів. 3 анамнезу слід визначити, на якому етапі почалися порушення функції відтворення у кішки, включаючи дані про те, у якому віці відбулася перша тічка, тривалість їі, а також тривалість анестрального періоду. Важливим є аналіз причин відсутності прояву статевої циклічності (первинного анеструсу, повторних анеструсів, “тихої охоти”). Крім того, анамнез має містити інформацію про застосовані медикаменти, щеплення, перенесені захворювання та особливості утримання кішки.

Дані зібраного анамнезу можуть свідчити, що клінічними ознаками неплідності, бувають: відсутність прояву тічки; відхилення перебігу статевого циклу (короткий термін інтер-проеструса, короткий проеструс або затяжний проеструс/еструс); неплідність на фоні фізіологічного перебігу статевого циклу; нездатність до парування чи переривання вагітності (Donoghue et al., 1992; Root et al., 1995; Stubbs et al., 1996; Liubetskyi \& Kharuta, 1997; Roth et al., 1997; Kraievskyi, 2006; Pope et al., 2006; Kholsta, 2008; Axner et al., 2008; Remillard, 2008).

Фізіологічний коефіцієнт фертильності у котячих важко визначити, бо він залежить від породи, а також кількості кошенят у приплоді. Для кішок фертиль- ність заснована на фізіологічному функціонуванні репродуктивної системи, включаючи процеси фолікулогенезу, овуляції, запліднення і відповідного середовища та стану матки для забезпечення процесу нідації зародків. У кішок овуляція відбувається рефлекторно під час спаровування, тому для успішного запліднення важливим елементом має бути правильна методика парування.

Під неплідністю розуміють тимчасову або тривалу втрату самками здатності до розмноження внаслідок різних причинних факторів або ж природжених чи набутих у процесі життя.

Залежно від причин, які обумовлюють неплідність самок, А.П. Студєнцов запропонував класифікацію, згідно з якою форми неплідності отримали такі назви: природжена, аліментарна, стареча, кліматична, експлуатаційна, симптоматична, штучно набута та штучно направлена. Останнім часом багато авторів звертають увагу й на таку форму неплідності, як імунну. Практично в основі кожної форми неплідності лежать причини, що іiї обумовлюють (Yablonskyi et al., 2008).

Природжена неплідність (стерилітет) - нездатність до відтворення як результат аномалій розвитку органів статевої системи самок, що виникають під час ембріонального та фетального розвитку або в результаті біологічної неповноцінності яйцеклітин, сперміїв, і як наслідок - неплідність.

Основними формами природженої неплідності самок $є$ інфантилізм, фримартинізм і гермафродитизм. Крім того, природжена неплідність може виявитися наявністю чотирьох чи одного яєчника або ж їх відсутністю, зростанням яєчників 3 брижейкою, природженим склерозом яєчників, відсутністю ділянок яйцепроводів або їх сфінктерів, заростанням каналу шийки матки, одно- або трирогою маткою тощо.

Інфантилізм - це природжена недорозвиненість органів статевої системи. Яєчники мають дрібний розмір, в них відсутні жовті тіла, але є до чотирьох слаборозвинених фолікулів. Статеві цикли відсутні.

Гермафродитизм - це наявність в однієї тварини ознак самки та самця. Гермафродитизм буває справжнім, коли у самки є один яєчник і один 
сім'яник або тканини сім'яника та яєчника, а також несправжнім, коли за наявності вторинних статевих ознак самки, а також матки, піхви та петлі є тканини і сім'янники при відсутності яєчників. Ступінь відхилення нормальної самки коливається від досить незначних у несправжніх гермафродитів до наявності майже всіх вторинних статевих ознак самця і самки у справжніх гермафродитів.

Причини гермафродитизму - відхилення у гормональному статусі в організмі плодів в період розвитку, але найчастіше ймовірно, в ембріональний період розвитку, коли відбувається започаткування i формування систем органів i тканин. Генетично абсолютна більшість гермафродитів $є$ самками, i тільки в окремих порід 3 двома або трьома жіночими хромосомами існує одна чоловіча, тобто фактично клітини мають триплоїдний або тетраплоїдний набір хромосом. Таке явище пояснюється поліспермією під час запліднення.

Аномалії хромосомної статі чітко діагностують за даними визначення каріотипу. Зазвичай це визначення проводять на культурі лімфоцитів периферичної крові (Meyers-Wallen \& Patterson, 1989). Стан, при якому стать тварини невизначена через вродженні аномалії статевого тракту, називають інтерсексуальністю. Тварини з аномальним набором статевих хромосом зовні виглядають як нормальні самці та самки, які володіють скоріше недорозвинутими, аніж невизначеними статевими органами. Винятками з цього правила можуть бути тварини-мозаїки та химери. Більшість тварин 3 аномальним набором статевих хромосом неплідні, способів лікування немає (MeyersWallen \& Patterson, 1989). Фертильний оваріальний цикл спостерігається у самок з генотипом XXX. Причиною цього синдрому $\epsilon$ нерозходження статевих хромосом. Химера - це особа, клітини якої представлені двома популяціями, що відрізняються за своїм походженням. Так, якщо джерелом походження однієї популяції буде організм XX, а другої - XY, то буде розвиватися химера $\mathrm{XX} / \mathrm{XY}$. Мозаїк характеризується наявністю двох генетичних різних популяцій клітин, але всі його клітини мають спільне походження (одну і ту саму зиготу). Порушення виникає внаслідок нерозходження хромосом у процесі мітозу, зазвичай на стадії дроблення зиготи. В результаті цієї помилки утворюються чотири популяції клітин - YО, XXY, $\mathrm{XO}, \mathrm{XYY}$, і достатньо одній із них вижити поряд 3 нормальними клітинами, щоб виник мозаїцизм, наприклад XY/XXY, XY/XYY чи XY/XO (Amann \& Veeramachaneni, 2007; Szczerbal et al., 2015; Balogh et al., 2015; Szczerbal et al., 2017).

Істинний гермафродит володіє оваріальною та тестикулярною тканиною. Одна гонада може бути яєчником, а друга сім'яником або комбінацією із яєчника i тестикула. Зазвичай жіночі псевдогермафродити виникають, коли препарати тестостерону або прогестерон задаються матері під час вагітності. Ці тварини часто стерильні, але їх не слід розводити, навіть якщо вони плідні. Агенезія - вроджена відсутність яєчника. Внутрішня гіпоплазія (гіпофункція) яєчників - ендо- кринне захворювання, обумовлене порушенням функцій гіпоталамо-гіпофізарної системи. Причинами гіпоплазії яєчників можуть бути пухлини гіпоталамуса або гіпофіза, травми, опромінення, інтоксикація. Однією 3 причин пошкодження функцій яєчників можуть бути генетичні мутації, які проявляються в період раннього онтогенезу або розвитку тварин. Усі вищеперелічені аномалії спричиняють неплідність самок.

Фримартинізм є результатом розвитку однояйцевих двійнят у фактично однорідних тварин, в яких загальною $є$ зовнішня (судинна, хоріон) оболонка, і між судинами самця і самки через існуючі анастомози кров обох плодів змішується. 3 цієї причини, починаючи вже 3 моменту формування оболонок i плацентарного кола кровообігу, гормональні фактори чоловічої статі блокують гормоносинтез залоз внутрішньої секреції жіночої статі, а це призводить до порушення органогенезу в органах статевої системи самки.

При фримартинізмі в самок відзначається перерозвиненість клітора чи найрізноманітніші аномалії розвитку матки.

Однією 3 основних причин появи різновидів природженої неплідності у самок, за даними більшості авторів, є близькородинне розмноження.

Стареча неплідність (стерилітет) - нездатність до відтворення у зв'язку з віком як результат старечої атрофії матки та яєчників, а також інших відділів статевої системи. Поряд 3 морфологічними змінами органів статевої системи різко знижується i їх функціональна діяльність, що характеризується різкими змінами в гормональному статусі організму.

Симптоматична неплідність - це порушення плодючості як результат патології статевих та інших органів і систем організму у самок. Тому цю неплідність слід розглядати як наслідок захворювання, а до них можна зарахувати: вульвовагініт, метрит, піометра, гідро- і піосальпінгіт, кісти яєчників та їх гіпофункцію, персистентні жовті тіла та інші гінекологічні захворювання. Серед гінекологічних захворювань у кішок найпоширенішими захворюваннями є піометра, ендометрит та вагініт (Kholsta, 2008).

Однією з основних причин порушення репродуктивної функції у кішок $є$ хронічний ендометрит. Проаналізувавши велику кількість досліджень стосовно хронічного ендометриту у різних видів тварин (Stubbs et al., 1996; Liubetskyi \& Kharuta, 1997; Kraievskyi, 2006; Feldman \& Nel'son, 2008; Kustritz, 2010; Omelianenko \& Chuprun, 2014) можна зробити висновок, що первинним фактором виникнення захворювання є гормональні зміни, які ускладнюються зниженням резистентності ендометрію та його кістозною гіперплазією. Найчастіше діагностованим i таким чином найбільш важливим захворюванням матки собак і котів $є$ кістозна гіперплазія ендометрію в комплексі з піометрою (КГЕ-П). Однак його поширеність зменшується із застосуванням ранньої оваріогістеректомії. 
Кістозна гіперплазія ендометрію (КГЕ), що супроводжує піометру в кішок, спостерігається рідше, ніж у собак. Клінічні прояви виникають як у тварин, що були вагітними, так і в тих кішок, які не виношували плода. Дослідники вважають, що менша кількість випадків захворювання на піометру серед кішок пов'язана $з$ тим, що, по-перше, овуляція у них виникає лише за умови в'язки, тому матка не піддається впливу прогестерону і кістозні зміни в ендометрію не розвиваються. По-друге, прогестеронова фаза, яка виникає після овуляції, у кішок значно коротша, ніж у собак (Omelianenko, 2001; Feldman \& Nel'son, 2008; Igna et al. 2009).

Чупрун Л.О. (Chuprun, 2008; Chuprun, 2011; Omelianenko \& Chuprun, 2014) вважає, що незалежно від породи і пори року в кішок віком від 8 місяців до 14 років піометра найчастіше виникає як ускладнення гнійно-катарального ендометриту або інфікування матки після застосування гормональних препаратів для пригнічення стадії збудження статевого циклу. Основною причиною піометри є контамінація піхви клінічно здорових кішок стрептококами, стафілококами та кишковою паличкою, які при зниженні резистентності організму проникають у матку i викликають запальний процес. На думку автора, патогенез піометри зумовлюють: розмноження мікроорганізмів у матці та виділення ними токсичних ферментів, що руйнують епітелій i тривалий час подразнюють оголений ендометрій, викликає інфільтрацію ендометрію лейкоцитами, гіперплазію i гіпертрофію залоз, що $\epsilon$ захисним бар'єром на шляху їх проникнення в глибину стінки матки; підвищення вірулентності збудників запалення супроводжується прогресуючою захисною реакцією, що проявляється мерокриновою i голокриновою секрецією залоз і ускладнюється їх кістозним переродженням 3 оголенням стінок і їх розривом та утворенням різної величини і форми порожнин.

Поширеність гіперпластичних аномалій ендометрію у кішок статевих органів зростає з віком і найчастіше зустрічається у тварин віком понад п'ять років. У $39 \%$ кішок ураження були виявлені безпосередньо під час оваріогістеректомії або при аутопсії. Поширеність ендометритів і піометри у кішок була пов'язана зі збереженими жовтими тілами принаймні в одному яєчнику.

Пухлини матки досить рідкісна патологія у кішок i складає 0,29\% (Brodey, 1970). Також у кішки може наступити безперервна або пролонгована тічка. Вона стає дратівливою, не підпускає до себе котів, а іноді, навпаки, безперервно злучається (німфоманія), але вагітність не наступає. Проте й інші чинники можуть відігравати ключову роль в етіології виникнення цієї патології. Окремі дослідники експериментально спровокували гіперплазію ендометрію шляхом внесення шовкової хірургічної нитки в просвіт матки під час діеструсу. Встановлено, що естрогени посилють дію прогестерону, пришвидшуючи розвиток кістозної гіперплазії ендометрію (Barnette, 2018).
Аліментарна неплідність - це порушення плодючості самок внаслідок їх надмірної, недостатньої або ж неякісної годівлі. Ознаки цієї неплідності характеризується порушенням статевих циклів, термінів овуляції, малоплідністю або ж народженням слабкого приплоду із малою вагою. Насамперед ця форма неплідності обумовлена нестачею в раціоні вітамінів, мінеральних речовин і білка. Неправильна годівля служить чи не найголовнішою причиною неплідності у котячих. Проблеми будуть як у особин з недостатньою вагою, так і з надмірною масою тіла. Неплідність реєструють при нестачі і (або) надлишку в раціоні Кальцію, Фосфору, Йоду, Кобальту, Купруму, Мангану, інших макро- і мікроелементів. Порушуються процеси, пов'язані з дозріванням фолікулів в яєчнику, овуляцією, формуванням і розсмоктуванням жовтих тіл. Нерідко утворюється персистентне жовте тіло. Можуть розвиватися кісти яєчників. При різко вираженому тривалому порушенні фосфорнокальцієвого мінерального живлення анафродизія може бути дуже тривалою або навіть постійною (Barnette, 2018).

Експлуатаційна неплідність - це порушення плодючості самок внаслідок їх однобічної та надмірної експлуатації. Ця форма експлуатації виникає там, де практикують в'язки в кожний еструс та тривалий підсисний період.

Кліматична неплідність - це порушення плодючості самок внаслідок гальмування відтворної функції метеорологічними факторами, зміни кліматичної зони життя самок, а також порушення умов догляду та утримання, різких контрастів мікроклімату в приміщенні. Усі ці фактори варто враховувати при транспортуванні самок 3 однієї кліматичної зони в іншу, навіть в межах однієї області, при заміні приміщення утримання. Слід пам'ятати, що наочна адаптація (макроадаптація) у самок відбувається досить швидко (до нових власників, місця утримання, корму та інше), а фізіологічна, включаючи і відтворну функцію, - це процес досить затяжний, що необхідно пам'ятати спеціалістам різного рівня, які безпосередньо займаються розведенням кішок.

Штучно набута неплідність - це порушення плодючості окремих видів самок внаслідок неправильної організації і проведення штучного осіменіння або природного парування.

Імунна неплідність - імунологічні суперечності між сперміями і яйцеклітинами призводять до того, що запліднення взагалі не відбувається або ж ембріони гинуть на різних стадіях їх розвитку. Відсутність запліднення кішок після їх осіменіння може бути пов'язане 3 швидкою аглютинацією сперміїв в статевому апараті під впливом спермоантитіл (спермоаглютинінів). Після введення сперми спермії втрачають свою здатність рухатися i брати участь у заплідненні.

Порушення статевого циклу в кішок бувають досить часто i виникають на рівні гіпоталамогіпофізарного комплексу i яєчників, проявляючись 
при цьому у вигляді різних симптомів, деякі з яких можуть бути патогномонічними ознаками захворювань генітальної та екстрагенітальної природи. Проявляються анестрією, гіпоастральним, гіперестральним, анестральний, поліестральним синдромами . Анестрія може бути обумовлена первинним ураженням яєчників, або порушенням регуляції на рівні ендокринної системи головного мозку. Внаслідок цього порушення функції гіпофіза та гіпоталамуса призводить до зменшення продукції релізинг-гормонів (фоліберин, люліберин) і гонадотропних гормонів - фолікулостимулюючого і лютеїнізуючого гормонів (ФСГ, ЛГ). В розвитку анестрії також можуть відігравати як генетичні, так і зовнішні фактори.

При гіпоестральному синдромі ознаки проеструсу та еструсу слабо виражені. Основною причиною гіпоестрального синдрому $є$ недостатня секреція преовуляторними фолікулами естрогенів. При гіперестральному синдромі ознаки проеструсу та еструсу добре виражені. При розвитку гіперестрального синдрому персистуючі анвуляторні фолікули секретують велику кількість естрогенів. Відсутність овуляції обумовлено недостатньою секрецією передньою долею гіпофізу ЛГ. Після закінчення затяжної тічки або їі корекції за допомогою гормональних препаратів часто утворюються фолікулярні кісти. Присутність кіст в яєчниках у стадії діеструсу свідчить про схильність до утворення гідро-, або піометри.

При анестральному синдромі трапляється порушення статевого циклу, при якому інтервал між тічками перевищує 6 місяців. Подовження межестрального періоду виникає за рахунок стадії анеструсу. Таку клінічну картину спостерігають у кішок віком понад 8 років. Схильністю до даного синдрому є гіпотеріоїдоз і гіперадренокортицизм, ожиріння і кахексія, призначення препаратів з антигонадною активністю.

Постдіестральний синдром проявляється внаслідок регресії жовтого тіла після закінчення статевого циклу і характеризується розвитком у кішок ознак родової діяльності, лактації. Таку картину можна спостерігати після проведення оварієктотомії в стадії дії еструсу, трапляється досить часто. Несправжна лактація $є$ причиною виникнення маститу, мастопатії та злоякісних новоутворень в молочних залозах (Barnette, 2018).

Недостатня овуляція у більшості випадків відзначається в кінці естрального циклу. Важливо провести кілька спарювань, оскільки одне не завжди призводить до овуляції. Після овуляції підвищується рівень прогестерону в крові. Проба на прогестерон стає позитивною на сьомий день після еструса і зберігається до сорокового дня. Якщо рівень прогестерону в крові не піднявся, значить - овуляції не було (Tsutsui et al., 2009; Gary, 2010).

Хоча початок і тривалість активності яєчників залежить від географічної широти місцевості та породи кішки, головним фактором є довжина періоду світлового дня. Недостатність інтенсивності та тривалості освітлення $\epsilon$ головними причинами подовженого анеструсу в кішок, що утримуються в приміщенні.
Відсутність бажання спарюватися потенційно пов'язане 3 гормональними проблемами або віком. Недостатня стимуляція у кішок є однією 3 найпоширеніших причин неплідності, що актуально саме для кішок, тому що для них характерна індукована овуляція. Багатьом тваринам при цьому потрібні множинні в'язки, тому що один статевий акт може дати недостатній стимулюючий ефект. У заляканих кішок характерна для еструсу поведінка інколи буває пригніченою. Тому рекомендовано утримувати тварину до появи перших ознак еструсу у звичних для неї умовах. У випадку неприйнятті кішкою кота потрібно вручну стимулювати статеву активність та утримувати ії до контакту з котом.

Важливу роль у виникненні неплідності в кішок відіграють інфекційні захворювання. Вірус лейкемії кішок може викликати різні захворювання репродуктивного тракту, включаючи резорбцію ембріонів, аборти, народження інфікованої потомства. Вірус здатний долати плацентарний бар'єр, але фактично аборти є результатом вторинної бактеріальної інфекції на тлі імуно-супресивної дії вірусу лейкемії (Barnette, 2018).

Герпесвірусна інфекція іноді призводить до спонтанного аборту на 5-му або 6-му тижні вагітності. Захворювання панлейкопенію на ранніх термінах вагітності викликає аборт, тимчасом як інфікування в кінці вагітності призводить до розвитку церебральної гіпоплазії плодів і мертвонародження. Аборт протягом двох останніх тижнів вагітності нерідко відбувається в результаті інфікування вірусом інфекційного перитоніту котів. Вірус може також викликати ендометрит, мертвонародження, хронічні захворювання верхніх дихальних шляхів і синдром “згасання кошенят”. Інфікування токсоплазмозом спричиняє внутрішньоутробне зараження кошенят або аборт (в окремих випадках). Наявність даних мікроорганізмів виявляють за допомогою серологічних досліджень. Хламідії, що вражають кішок, можуть викликати спонтанний аборт. Етіологія аборту і спосіб передачі інфекції невідомі, хоча збудника виявляють в репродуктивному тракті кішок після викидня (Barnette, 2018).

Для діагностики неплідності використовують ряд досліджень. Одним з основних таких методів діагностики неплідності у кішок $є$ визначення рівня статевих гормонів в крові, зокрема прогестерону та естрадіолу. Встановлено, що породна характеристика кішок не впливає на рівень стероїдогенезу. Концентрація естрадіолу та прогестерону у кішок віком 4-6 місяців перебуває на базальному рівні. У віці 7-12 місяців відбувається статеве дозрівання кішок. У цей період рівень естрадіолу зростає до 72,14 і 78,14 пг/мл, а прогестерону - 16,6 і 19,60 нг/мл, відповідно у фолікулярну та лютеїнові фази. Максимальна концентрація статевих стероїдів спостерігається у кішок віком 13-60 місяців. У кішок віком понад п'ять років вміст естрадіолу та прогестерону в сироватці крові поступово зменшується, проте залишається у фізіологічних межах. Концентрація кортизолу збільшується у про- 
цесі статевого дозрівання кішок та досягає максимальних значень у тварин, віком понад 5 років (Wildt et al., 1978; Tsutsui et al., 1989; Kamyshnikov, 2000; Verstegen, 2005; Gary, 2010).

Вагінальна цитологія відображає гормональні зміни в організмі кішок, особливо в період тічки. Даний метод в племінному розведенні кішок застосовується рідше, ніж у собак, оскільки процедура може вплинути на хід циклу. Під час фази зростання фолікулів у виділеннях виявляються поверхневі кератинізовані клітини, наявність яких пояснюється впливом 17бета-естрадіолу. Процентний вміст без'ядерних поверхневих клітин зростає незначно. У період фолікулярної фази основною характеристикою вагінальних виділень $\epsilon$ повільне скорочення кількості клітин, що містять ядро, проміжних і базальних клітин. Однак зазначені зміни у кішок менше виражені, ніж у сук.

Найбільш значущим індикатором активності естрогену є освітлення фону на предметному склі, пов'язане з різким скороченням уламків розпушених клітин i слизу. Зміст еозинофілів помітно нижчий, ніж у собак, еритроцити відсутні. Для інтереструсу характерно переважний вміст проміжних клітин 3 невеликим включенням базальних, парабазальних і кератинізованих клітин. Загалом саме уламки клітин надають препаратам характерного вигляду. На стадії анеструсу клітин небагато . Виділення містять в основному слиз, базальні і парабазальні клітини з рідкісним включенням проміжних клітин. У деяких випадках наявні лейкоцити. Вагінальна цитологія застосовується для встановлення або підтвердження фолікулярної фази (проеструсу або еструсу). Виявлення сперміїв невдовзі після копуляції дозволяє підтвердити факт в'язки (Verstegen, 2005).

Основним для оцінки вагінального мазка $є$ те, що ороговілі супефіціальні клітини легко відрізняються від інших клітин. Оскільки ороговілі епітеліальні клітини реагують ацидофільно, а неороговілі - базофільно, їх можна пофарбувати за допомогою поліхроматичного методу (Kamyshnikov, 2000; Kovalov, 2003).

Класичном методом фарбування за Папаніколау ороговілі суперфіціальні клітини фарбуються червоно-помаранчевим кольором, всі інші - синьо-зеленим. На жаль, цей метод $є$ дуже трудомістким і забирає багато часу, необхідного в багатьох випадках для миттєвого рішення.

На практиці добре зарекомендував себе метод фарбування Кубічека. Це також поліхроматичний метод фарбування, який можна здійснювати за декілька хвилин і без великих затрат сил і коштів. Цей метод дозволяє також добре розрізняти клітини, як і метод Папаніколау. В обробленому препараті ороговілі клітини мають помаранчевий колір, всі інші - cipoзелений.

Досвідченим цитологам, які добре відрізняють різні види епітеліальних клітин лише на основі їх морфології, для вагінально-цитологічної діагностики достатньо простого методу фарбування із гематології (за Гімзою або Diff Quick) (Barnette, 2018).
При фарбуванні за Гімзою “лусочки” фарбуються в темно-синій колір, ектоплазма - голуба, ядра - сині. Лейкоцити - темно-сині.

Важливими критеріями оцінки клітин в мазку є їхні розміри, форма, співвідношення між ядром і цитоплазмою і наявність речовини клітинного ядра. В міру того, як в крові зростає рівень естрогенів, клітини в вагінальному мазку проходять еволюцію від неороговілих (нормальних, круглої форми клітин) до ороговілих (мертвих, плоских клітин). Як тільки наступає зниження рівня естрогенів, кількість неороговілих клітин повертається до норми і кішка виходить зі стану тічки. В вагінальному мазку наявні чотири неповні типи клітин, 3 деякими варіаціями кожного 3 них. По-перше, парабазальні клітини - неороговілі, 3 великим ядром. Проміжні клітини - повністю або частково ороговілі з меншим ядром, ніж в парабазальних клітинах. Крім цього, поверхневі клітини ороговілі, з дуже маленьким ядром або сегментарним (яке ділиться). I, нарешті, ороговілі клітини, в яких ядро відсутне повністю. Ці чотири типи клітин з'являються приблизно в наведеній вище послідовності - парабазальні, проміжні, поверхневі (неороговілі суперфіціальні), без'ядерні (ороговілі суперфіціальні) (Kamyshnikov, 2000; Kovalov, 2003).

Гістеросальпінгограма (ГСГ) - цей тест має важливе значення для оцінки прохідності маткових труб, наявності новоутворень у матці, таких як міома, поліпи, також наявність рубців у порожнині матки. Значна кількість аномалій матки та яйцепроводів, виявлені за допомогою ГСГ, можуть бути хірургічно усунені (Barnette, 2018).

У окремих випадках можна застосовувати рентгенографічний метод для виявлення окремих аномалій у репродуктивних органах.

Особливе значення для діагностики піометри має УЗД та цитологічне дослідження виділень (Brodey, 1970; Kondrashin et al., 2000; Tilli \& Smit, 2001; Wolfgang, 2004; Frensis, 2006; Lopate, 2012).

Транскутанне ультразвукове дослідження - УЗД $є$ важливим інструментом в оцінці структури матки, яйцепроводів та яєчників. Застосування ультразвукової діагностики дає змогу діагностувати такі патології матки, як фіброми, поліпи, оклюзія дистальних фаллопієвих труб та патології яєчників, включаючи кісти яєчників (Barnette, 2018).

Варто зазначити, що за останні роки ветеринарна репродуктологія зробила вагомий крок вперед, але залишилися нез'ясованими деякі питання щодо етіології та діагностики захворювань, що призводять до неплідності кішок.

Необхідно досконало вивчити всі причини, які призводять до даного захворювання, розробити сучасну та більш точну діагностику неплідності, що дозволить власникам кішок отримати максимальну кількість здорових кошенят.

\section{References}

Agudelo, C.F. (2005). Cystic endometrial hyperplasia - 
pyometra complex in cats. A review. Vet Q, 27(4), 173182. https://www.ncbi.nlm.nih.gov/pubmed/16402514.

Amann, R.P., \& Veeramachaneni, D.N. (2007). Cryptorchidism in common eutherian mammals. Reproduction 133(3), 541-561. doi: 10.1530/REP-060272 .

Axner, E. (2010). Nieplodna kotka - podejscie kliniczne. Poloznictwo i neonatologia psa i kota (Gary C.W.England, Angelika von Heimendal, Wojciech Nizanski). BSAWA - ELSEVIER, 67-73.

Axner, E., Agren, E., Baverud, V. \& Holst, B.S. (2008). Infertility in the cycling queen: seven cases. Journal of Feline Medicine and Surgery, 10(6), 566-576. doi: 10.1016/j.jfms.2008.04.005.

Balogh, O., Berger, A., Pienkowska-Schelling, A., Willmitzer, F., Grest, P., Janett, F., Schelling, C., \& Reichler, I.M. (2015). 37,X/38,XY mosaicism in a cryptorchid Bengal cat with Mullerian Duct Remnants. Sexual Development, 9(6), 327-332. doi: 10.1159/000443233.

Barnette, C. (2018). Infertility in Female Cats https:/vcahospitals.com/know-your-pet/infertility-infemale-cats.

Brodey, R.S. (1970). Canine and feline neoplasia. Adv. Vet. Sci. Сотр. Med., 14, 309-354. https://www.ncbi.nlm.nih.gov/pubmed/4922146.

Chuprun, L.O. (2008). Perebih ta patomorfolohichni zminy v mattsi pry khronichnomu endometryti kishok. Naukovyi visnyk Lvivskoho natsionalnoho universytetu veterynarnoi medytsyny ta biotekhnolohii im. S.Z. Hzhytskoho, 10(2), 395-399 (in Ukrainian).

Chuprun, L.O. (2011). Piometra kishok: etiolohiia, patohenez, likuvannia: avtoreferat... kand. vet. nauk, spets.: 16.00.07 - veterynarne akusherstvo. Sumy : SNAU (in Ukrainian).

Donoghue, A.M., Johnson, L.A., Munson, L., Brown, J.L., \& Wildt, D.E. (1992). Influence of gonadotrophin treatment interval on follicular maturation, in vitro fertilization, circulating steroid concentrations, and subsequent luteal function in the domestic cat. Biology of Reproduction, 46(5), 972-980. doi: 10.1095/biolreprod46.5.972.

Feldman, Je., \& Nel'son, R. (2008). Jendokrinologija i reprodukcija sobak i koshek. Moskva: "Sofion" (in Russian).

Frensis, B. (2006), Ul'trazvukovaja diagnostika sobak i koshek. Moskva :Akvarium (in Russian).

Gary, C.W. (2010). England Fizjologia i endokrynologia rozrodu samic. Poloznictwo i neonatologia psa i kota (Gary C.W. England, Angelika von Heimendal, Wojciech Nizanski) - BSAWA - ELSEVIER, 1-13.

Igna, C. et al. (2009). Oestrus control with progesting end cystic endometrial hiperplazia-pyometra complex in the bitch. Lucrari Stiiniifice medicina Veterinara, XLII, 1-6. https://www.usab-tm.ro/vol9MV/76_vol9.pdf.

Igna, C., et al. (2009). Oestrus control with progesting end cystic endometrial hiperplazia-pyometra complex in the bitch. Lucrari Stiiniifice medicina Veterinara, XLII, 1-6.

Kamyshnikov, B.C. (2000). Spravochnik po klinikobiohimicheskoj laborotornoj diagnostike. Minsk: Bel- arus', 2, 495 (in Russian).

Kholsta, B.S. (2008). Zakhvoriuvannia kotiachykh, shcho peredaiutsia statevym shliakhom i pid chas shtuchnoho osimeninnia. Zdorovia dribnykh tvaryn, 9(48), 2-6 (in Ukrainian).

Kondrashin, S.A., Eremin, D.A., Koblinov, V.V. (2000). Ul'trazvukovaja diagnostika beremennosti melkih domashnih zhivotnyh: Materialy vos'mogo mezhdunarodnogo kongressa po problemam veterinarnoj mediciny melkih domashnih zhivotnyh. Moskva, 5556 (in Russian).

Kovalov, P.V. (2003). Tsytolohichna kartyna mazkiv iz pikhvy suk. Visn. Sumskoho nats. ahrar. un-tu, 9, 4850 (in Ukrainian).

Kraievskyi, A.P. (2006). Diahnostyka involiutsii, subinvoliutsii, pisliarodovoho endometrytu v koriv. Zhurnal vet. Medytsyny, 10, 21-22 (in Ukrainian).

Kustritz, M.R. (2010). Clinical canine and feline reproduction. University of Minesota college of veterinary medicine: Wiley Blackwell.

Liubetskyi, V.I., \& Kharuta, V. (1997). Dyferentsialna diahnostyka prykhovanoho endometrytu ta asotsiatsii hinekolohich-nykh khvorob. Akusherstvo, hinekolohiia, 8, 33-34 (in Ukrainian).

Lopate, C. (2012). Management of pregnant and neonatal dogs, cats, and exotic pets. USA: Wiley- Blackwell.

Meyers-Wallen, V.N., \& Patterson, D.F. (1989). Sexual differentiation and inherited disorders of sexual development in the dog. J Reprod Fertil Suppl., 39, 5764. https://www.ncbi.nlm.nih.gov/pubmed/2695642.

Omelianenko, M.M. (2001). Rozpovsiudzhennia akusherskykh i hinekolohichnykh zakhvoriuvan suk i kishok ta yikh likuvannia. Naukovyi visnyk Natsionalnoho ahrarnoho universytetu, 42, 114-118 (in Ukrainian).

Omelianenko, M.M., \& Chuprun, L.O. (2014). Piometra kishok: Monohrafiia. Zhytomyr: "Polissia" (in Ukrainian).

Pope, C.E., Gomez, M.C., \& Dresser, B.L. (2006). In vitro embryo production and embryo transfer in domestic and non-domestic cats. Theriogenology, 66(6-7), 15181524. doi: 10.1016/j.theriogenology.2006.01.026.

Remillard, R.L. (2008). Homemade diets: attributes, pitfalls and a call for action. Topics in Companion Animal Medicine, 23(3), 137-142. doi: $10.1053 /$ j.tcam.2008.04.006.

Rijnberk, Ad. et al. (2010). Clinical Endocrinology of Dogs and Cats. Hannover: Schlitersche.

Root, M.V., Johnston, S.D., \& Olson, P.N. (1995). Estrous length, pregnancy rate, gestation and parturition lengths, litter size and juvenile mortality in the domestic cat. Journal of the American Animal Hospital Association, 31(5), 429-433. doi: 10.5326/15473317-315-429.

Roth, T.L., Wolfe, B.A., Long, J.A., Howard, J.G., \& Wildt, D.E. (1997). Effects of equine chorionic gonadotrophin, and laparoscopic artificial insemination on embryo, endocrine and luteal characteristics in the domestic cat. Biology of Reproduction, 57(1), 65-71. doi: 10.1095/biolreprod57.1.165. 
Stubbs, W.P., Bloomberg, M.S., Scurggs, S.L., Shille, V.M., \& Lane, T.J. (1996). Effects of prepubertal gonadectomy on physical and behavioral developments in cats. J Am Vet Med Assoc, 209(11), 1864-1871. https://www.ncbi.nlm.nih.gov/pubmed/8944799.

Szczerbal, I., Nizanski, W., Dzimira, S., NowackaWoszuk, J., Ochota, M., \& Switonski, M. (2015). X monosomy in a virilized female cat. Reproduction in Domestic Animals, 50(2), 344-348. doi: $10.1111 /$ rda.12483.

Szczerbal, I., Stachowiak, M., Nowacka-Woszuk, J., Dzimira, S., Szczepanska, K., \& Switonski, M. (2017). Disorder of sex development in a cat with chromosome mosaicism 37,X/38,X,r(Y). Reproduction in Domestic Animals, 52(5), 914-917. doi: 10.1111/rda.12968.

Tilli, L., \& Smit, F. (2001). Veterinarija. Bolezni koshek i sobak: Per. s angl. GJeOTAR-MED, 607-608 (in Russian).

Tsutsui, T., Higuchi, C., Soeta, M. et al. (2009). Plasma LG, ovulation and conception rates in cats mated once on three times on different days on oestrus. Reproduction in Domestic Animals, 44(2), 76-78. doi: 10.1111/j.1439-0531.2009.01451.x.

Tsutsui, T., Sakai, Y., Matsui, Y., et al. (1989). Induced ovulation in cats using porcine pituitary gland prepa- ration during the non-breeding season. Japanese Journal of Veterinary Science, 51(4), 677-683. https://www.ncbi.nlm.nih.gov/pubmed/2511370.

Uillard, M., \& Gornval'd, G. (2004). Laboratornaja diagnostika v klinike melkih domashnih zhivotnyh. Moskva: Akvarium (in Russian).

Verstegen, Dzh. (2005). Osobennosti fiziologii i jendokrinologii koshek. V kn.: Rukovodstvo po reprodukcii i neonatologii sobak i koshek. Pod red. Dzh. Simpson, G. Ingland, M. Harvi. Moskva: Sofion (in Russian).

Wildt, D.E., Kinney, G.M., \& Seager, S.W.J. (1978). Gonadotrophin induced reproductive cyclicity in the domestic cat. Laboratory Animal Science, 28(3), 301307. https://www.ncbi.nlm.nih.gov/pubmed/682578.

Wolfgang, K. (2004). Veterinary reproductive ultrasonography horse, sheep, coat, pig, dog, cat. Germani, Schlitersche. http://vetbooks.ir/veterinaryreproductive-ultrasonography-horse-cattle-sheep-goatpig-dog-and-cat.

Yablonskyi, V.A., Khomyn, S.P., \& Kalynovskyi, H.M. (2008). Veterynarne akusherstvo, hinekolohiia ta biotekhnolohiia vidtvorennia tvaryn $\mathrm{z}$ osnovamy androlohii: pidruchnyk. Vinnytsia: Nova Knyha (in Ukrainian). 